\title{
Pemberdayaan Kelompok PKK Desa Ilomata melalui Wirausaha Keripik Pisang Aneka Rasa
}

\section{(Empowerment of PKK Group of Ilomata Village through Banana Chips Various Flavored Enterpreneurship)}

\author{
Tri Handayani ${ }^{*}$, Nurhayati Olii ${ }^{2}$, Kartika Chandra Pelangi ${ }^{3}$ \\ 1 Program Studi Teknologi Hasil Pertanian, Fakultas Pertanian, Universitas Ichsan Gorontalo, Jl. Drs. Achmad Nadjamuddin \\ No.10, Kota Gorontalo, Gorontalo 96115. \\ 2 Program Studi Manajemen, Fakultas Ekonomi, Universitas Ichsan Gorontalo, Jl. Drs. Achmad Nadjamuddin No.10, \\ Kota Gorontalo, Gorontalo 96115. \\ 3 Program Studi Teknik Informatika, Fakultas Ilmu Komputer, Universitas Ichsan Gorontalo, Jl. Drs. Achmad Nadjamuddin \\ No.10, Kota Gorontalo, Gorontalo 96115. \\ *Penulis Korespondensi: tri.handayani@mail.ugm.ac.id \\ Diterima Oktober 2019/Disetujui Maret 2021
}

\begin{abstract}
ABSTRAK
Desa Ilomata merupakan salah satu desa di Kabupaten Gorontalo yang memiliki potensi komoditi pertanian pisang, namun belum termanfaatkan secara optimal. Tujuan dari kegiatan pengabdian ini adalah memberdayakan kelompok PKK Desa Ilomata melalui kegiatan pelatihan pembuatan keripik pisang aneka rasa, pelatihan pembukuan sederhana dan pelatihan pemasaran produk. Metode yang diterapkan adalah pelatihan dan pendampingan yang kegiatannya meliputi 1) Pelatihan pembuatan keripik pisang aneka rasa; 2) Pelatihan pembukuan sederhana; 3) Pelatihan pemasaran produk; dan 4) Pendampingan penentuan nama produk, pembuatan label kemasan, dan pengurusan izin edar PIRT. Hasil kegiatan menunjukkan anggota kelompok PKK telah memahami dan memiliki keterampilan dalam membuat keripik pisang aneka rasa, melakukan pembukuan sederhana dan memasarkan produk. Tersedianya produk keripik pisang yang diberi nama keripik pisang I-Bas (Ilomata-Banana chips) dengan No. izin edar PIRT 214750201001324 dan telah dipasarkan baik secara offline maupun online. Dengan demikian, pemberdayaan kelompok PKK melalui wirausaha keripik pisang dapat meningkatkan pemanfaatan potensi komoditi pisang seiring dengan meningkatnya pemahaman dan keterampilan anggota kelompok PKK Desa Ilomata dalam membuat dan memasarkan produk keripik pisang aneka rasa.
\end{abstract}

Kata kunci: Ilomata, kelompok PKK, keripik pisang, pemberdayaan, wirausaha

\begin{abstract}
Ilomata Village is one of the villages in Gorontalo District which has the potential of banana farming commodities, but it has not been utilized optimally. The aim of this community service activity are empowering the Ilomata Village PKK group through training activities for making various flavors of banana chips, simple bookkeeping training and product marketing training. The method applied is training and mentoring, whose activities include 1) Training in making various flavored banana chips; 2) Simple bookkeeping training; 3) Product marketing training; and 4) Mentoring in determining the name of the product, making packaging labels, and handling PIRT distribution permit. The results of the activity showed that the PKK group members understood and had skills in making banana chips with various flavors, doing simple bookkeeping and marketing the product. The availability of a banana chip product named banana chips I-Bas (Ilomata-Banana chips) with No. distribution license for PIRT 214750201001324 and has been marketed both offline and online. Thus, the empowerment of the PKK groups through banana chips entrepreneurship can increase the utilization of the potential of the banana commodity in line with the increased understanding and skill of PKK group members in making and marketing various flavored banana chips products.
\end{abstract}

Keyword: banana chips, empowering, entrepreneurship, Ilomata, PKK

\section{PENDAHULUAN}

Salah satu jenis buah-buahan tropis yang banyak dikembangkan di Indonesia adalah pisang (Anggoro 2016). Pisang dapat tumbuh disembarang tempat sehingga produksi buahnya selalu tersedia dan dapat dijadikan produk yang cukup baik untuk pengembangan sumber pangan 
local (Suhartono 2011). Pisang dibedakan menjadi dua jenis yaitu pisang meja (bananas) dan pisang olahan (plantain) (Ekaputri 2013). Pisang kepok merupakan jenis pisang olahan karena pada umumnya dikonsumsi dengan dilakukan pengolahan terlebih dahulu seperti digoreng atau direbus.

Desa Ilomata, Kecamatan Tibawa, Provinsi Gorontalo memiliki luas wilayah 1.044 ha dengan jumlah penduduk 1.524 jiwa. Wilayah desa tersebut umumnya berbukit-bukit dengan penyebaran ketinggian antara 25-336 m, sehingga umumnya lahan di desa tersebut dipergunakan untuk perkebunan dan kehutanan. Data Balai Penyuluhan Pertanian Kecamatan Tibawa (2017) menyebutkan bahwa salah satu komoditas pertanian Desa Ilomata adalah pisang kepok. Luas lahan yang ditanami pisang oleh masyarakat desa sebesar 44,77 ha yang terbagi pada empat dusun, yaitu 4,79 ha di Dusun Tintayu; 17,19 ha di Dusun Kemiiri; 15,57 ha di Dusun Alpokat, dan 7,22 ha di Dusun Tuloa.

Potensi pertanian Desa Ilomata seharusnya dapat menjadi tumpuan untuk menggerakkan perekonomian desa kearah lebih baik, namun potensi tersebut belum dimanfaatkan secara optimal oleh warga. Salah satu olahan pisang yang pembuatannya cukup sederhana dan digemari masyarakat adalah keripik pisang (Mudjajanto \& Kustiyah 2006). Keripik pisang adalah makanan olahan dari buah pisang yang diiris tipis kemudian digoreng menggunakan minyak hingga buah pisang berubah warna dan teksturnya menjadi renyah (Nugraheni 2018). Menurut BSN (1996) Keripik pisang merupakan produk makanan ringan dibuat dari irisan buah pisang dan digoreng, dengan atau tanpa bahan tambahan makanan yang diizinkan. Berdasarkan analisis keuntungan yang dilakukan oleh (Hartoyo et al. 2019) menunjukan bahwa pisang yang diolah menjadi keripik pisang dapat dijadikan sebagai usaha berskala industri rumah tangga, dengan keuntungan usaha mencapai Rp. $5.200 / \mathrm{kg}$ dengan rasio keuntungan sebesar $65 \%$.

Desa Ilomata belum mempunyai kelompok usaha olahan pisang (keripik pisang) yang produknya dijual luas. Umumnya ibu-ibu hanya membuat keripik pisang tanpa inovasi rasa maupun kemasan, sehingga usaha keripik mereka tidak bertahan lama. Selain itu, anggota PKK yang pada umumnya adalah ibu rumah tangga juga belum memiliki pengetahuan dan keterampilan dalam mengatur keuangan usaha dan pemasaran produk. Sehingga, salah satu upaya yang dapat dilakukan adalah dengan membentuk kelompok wirausaha keripik pisang di Desa Ilomata melalui pemberdayaan organisasiorganisasi non formal seperti kelompok PKK. Pemberdayaan perempuan melalui pendidikan dan pelatihan memungkinkan kaum perempuan bisa berpikir rasional dan mampu menghasilkan ide-ide cemerlang yang bisa diterapkan sebagai kegiatan nyata di lapangan. Kegiatan nyata itu harus "laku jual" sehingga menghasilkan nilai tambah untuk kehidupan yang lebih sejahtera (Hamid et al. 2018). Tujuan dari kegiatan ini adalah memberdayakan anggota kelompok PKK Desa Ilomata melalui pelatihan pembuatan keripik pisang aneka rasa, pelatihan pembukuan sederhana dan pelatihan pemasaran produk.

\section{METODE PELAKSANAAN KEGIATAN}

\section{Lokasi dan Partisipan}

Program pengabdian masyarakat dalam bentuk pemberdayaan kelompok PKK Desa Ilomata dilaksanakan pada bulan Mei-Desember 2019. Lokasi kegiatan diselenggarakan di rumah produksi keripik I-Bas, Desa Ilomata, Kecamatan Tibawa, Kabupaten Gorontalo. Kegiatan pengabdian meliputi kegiatan pelatihan pembuatan keripik pisang aneka rasa, pelatihan pembukuan sederhana, pelatihan pemasaran, dan pendampingan. Peserta kegiatan adalah anggota kelompok PKK Desa Ilomata, Kecamata Tibawa, Kabupaten Gorontalo yang berjumlah 10 orang.

\section{Bahan dan Alat}

Bahan yang digunakan dalam kegiatan pengabdian masyarakat ini meliputi: 1) Bahan dan alat pelatihan pembuatan keripik pisang aneka rasa, yaitu buah pisang kepok mentah dengan kulit berwarna hijau, bumbu tabur aneka rasa (cokelat, balado, keju manis, dan barbeque), minyak goreng, gula pasir, air, kompor, peralatan penggorengan, alat pengiris keripik, baskom, wadah aluminium, plastik kemasan, hand sealer, sendok, sarung tangan plastik, dan celemek. 2) Bahan dan alat untuk pelatihan pembukuan sederhana dan pelatihan pemasaran produk, yaitu materi pelatihan, LCD, laptop, buku, peralatan menulis, kertas HVS, buku jurnal, buku besar keuangan, kertas stiker, dan printer.

\section{Bentuk Kegiatan \\ - Kegiatan pelatihan}

Pelatihan pembuatan keripik pisang aneka rasa. Kegiatan ini diawali dengan pembenahan tempat produksi dan pemberian sejumlah per- 
alatan produksi kepada kelompok PKK Desa Ilomata yang dapat menunjang kegiatan pelatihan dan berdirinya usaha keripik pisang. Adapun tahapan dalam pembuatan keripik pisang aneka rasa yaitu pisang dibersihkan, dikupas dan dicuci. Selanjutnya pisang diiris di atas minyak yang sebelumnya telah dipanaskan. Selama penggorengan, keripik pisang dibolakbalik hingga berwarna kuning kecokelatan dan ditambahkan $10 \mathrm{~mL}$ air gula dengan cara disiramkan pada keripik setiap kali penggorengan. Selanjutnya keripik ditiriskan dan dicampurkan pada 50 g bumbu aneka rasa (cokelat, balado, keju manis, dan barbeque) (Gambar 1). Keripik pisang yang dihasilkan kemudian ditimbang sebanyak $100 \mathrm{~g}$ dan dikemas dalam kemasan plastik zipper berbahan Polypropylene (PP) dengan ukuran 12 × 20 x 0,1 cm dan ketebalan 100 mikron yang bertujuan untuk menjaga produk agar tidak mudah rusak (dalam artian remuk atau tidak utuh bila diletakkan sembarangan).

Pelatihan pembukuan sederhana berupa pelatihan yang diberikan kepada anggota kelompok PKK di mana peserta dilatih untuk mencatat

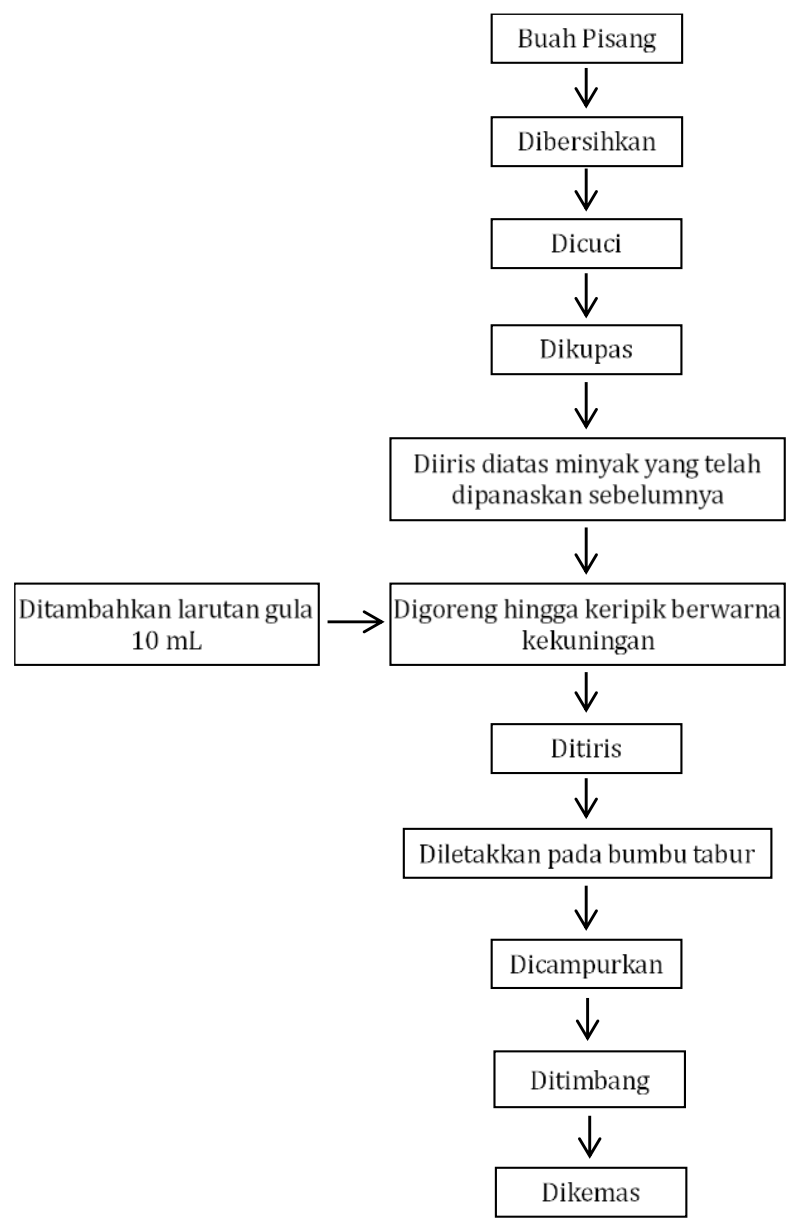

Gambar 1 Diagram alir pembuatan keripik pisang aneka rasa. semua pendapatan dan semua pengeluaran pada buku jurnal. Selanjutnya dilakukan pencatatan pada buku besar.

Pelatihan pemasaran produk meliputi pelatihan pemasaran offline maupun online. Pelatihan pemasaran offline dalam bentuk pelatihan mempromosikan/menawarkan produk keripik melalui orang-orang terdekat, menitipkan di kios-kios maupun rumah makan, dan melalui jejaring PKK. Sedangkan pelatihan pemasaran online berupa pelatihan memasarkan produk melalui sosial media yang dimiliki oleh peserta.

\section{- Kegiatan pendampingan}

Pendampingan dalam kegiatan pengabdian ini berupa pendampingan dalam penentuan nama produk, pembuatan label kemasan, dan pengurusan izin edar PIRT (Pangan Industri Rumah Tangga).

\section{HASIL DAN PEMBAHASAN}

\section{Pelatihan Pembuatan Keripik Pisang Aneka Rasa}

Pelatihan merupakan serangkaian aktivitas yang dirancang untuk meningkatkan keahlian, pengetahuan, pengalaman ataupun perubahan sikap seorang individu. Pelatihan berkenaan dengan perolehan keahlian-keahlian atau pengetahuan tertentu (Santoso 2010). Kegiatan pengabdian masyarakat ini diawali dengan pembenahan tempat produksi dan pemberian sejumlah peralatan produksi kepada kelompok PKK Desa Ilomata yang digunakan untuk menunjang kegiatan pelatihan dan berdirinya usaha keripik pisang (Gambar 2). Selanjutnya dilaksanakan kegiatan pelatihan pembuatan keripik pisang aneka rasa, pelatihan pembukuan sederhana, dan pelatihan pemasaran produk.

Tujuan pelatihan ini adalah agar anggota kelompok PKK Desa Ilomata memiliki keterampilan dalam membuat keripik pisang aneka rasa. Pelatihan ini dilaksanakan di salah satu bangunan milik desa yang jarang digunakan yang kemudian dijadikan sebagai rumah produksi keripik oleh ibu ketua kelompok PKK. Pelatihan ini berupa praktik langsung dalam membuat keripik pisang aneka rasa. Tahapan kegiatannya mengikuti diagram alir pembuatan keripik pisang pada Gambar 1. Pada pelatihan pembuatan keripik pisang ini, anggota kelompok PKK juga diberikan pelatihan pengemasan produk. Pelatihan ini berupa pemberian informasi cara 


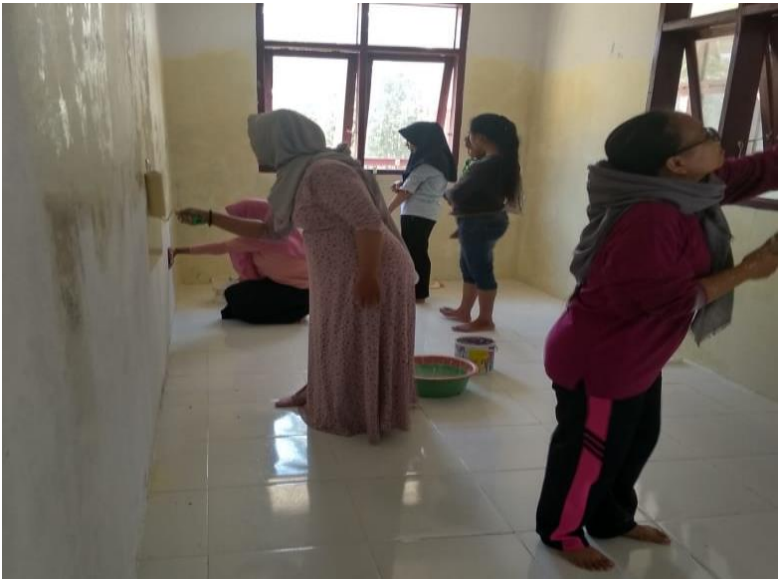

a

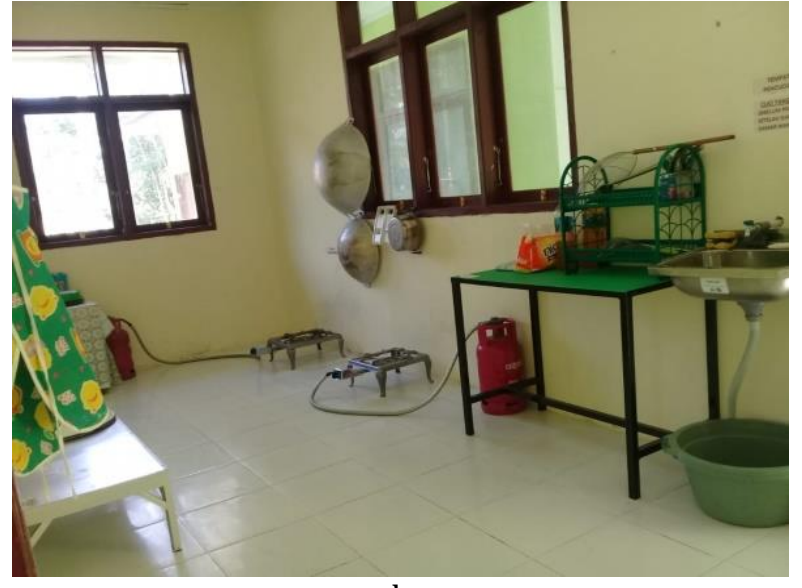

b

Gambar 2 a) Penyiapan tempat produksi dan b) Pemberian bantuan peralatan.

membedakan jenis-jenis kemasan berdasarkan bahan dan peruntukannya, cara mengemas produk keripik pisang, serta cara menggunakan hand sealer. Kemasan yang digunakan, yaitu kemasan plastik zipper yang berbahan polipropilena (PP). Kemasan dapat mempengaruhi umur simpan produk. Umur simpan keripik pisang pada suhu ruang $\left(25^{\circ} \mathrm{C}\right) 143,52$ hari dalam kemasan polipropilena (Puspita 2016). Kemasan yang baik selain dapat melindungi dari berbagai cemaran fisik, kimia, maupun biologi juga dapat berfungsi untuk menarik minat konsumen terhadap produk yang dijual. Hasil dari kegiatan pelatihan ini adalah 1) Anggota kelompok PKK Desa Ilomata telah memahami dan memiliki keterampilan dalam membuat keripik pisang aneka rasa dan pengemasan produk; 2) Dihasilkannya produk keripik pisang dengan lima varian rasa, yaitu original, cokelat, balado, keju manis, dan barbeque (Gambar 3).

Adapun kendala dalam pelatihan ini adalah irisan keripik yang kadang tidak sama (ada yang tipis dan ada yang tebal) akibat terlalu ditekan saat pengirisan. Selain itu, bumbu tabur yang diberikan pada beberapa keripik terlihat tidak merata (ada yang terlalu tebal). Sehingga kedepannya anggota PKK perlu banyak melakukan latihan secara mandiri terkait keterampilan mengiris dan mencampur keripik dengan bumbu tabur agar lebih merata.

\section{Pelatihan Pembukuan Sederhana}

Pembukuan keuangan usaha merupakan parameter yang dapat digunakan untuk melihat apakah UMKM tersebut maju atau tidak. Pelatihan pembukuan sederhana mengajarkan kepada kelompok PKK agar memiliki keterampilan dalam pembukuan keuangan usaha dan tidak lagi menggabungkan antara keuangan

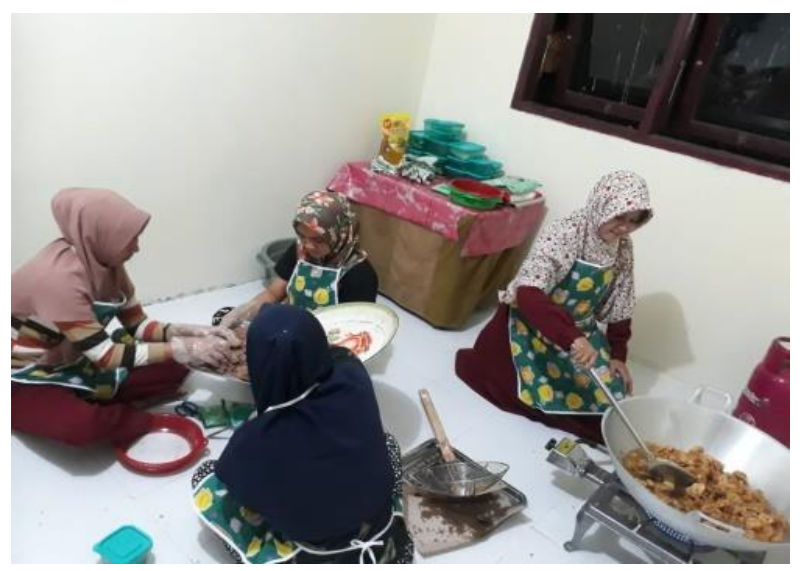

a

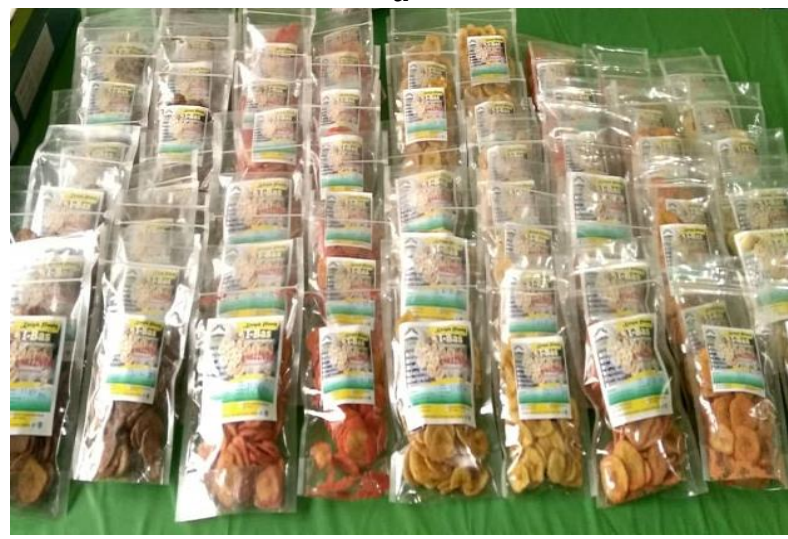

b

Gambar 3 a) Pelatihan pembuatan keripik pisang aneka rasa dan b) Produk yang dihasilkan.

usaha dengan keuangan pribadi. Sehingga manfaat melakukan pembukuan bagi usaha kecil dapat dirasakan seperti meminimalisasi kelebihan pengeluaran, mengetahui untung atau tidaknya sebuah bisnis, membantu strategi bisnis selanjutnya, memudahkan pelaporan pajak, memberikan gambaran jelas bagi kreditur, dan investor (Rinaldo et al. 2018).

Pelatihan pembukuan sederhana bagi anggota kelompok PKK Desa Ilomata dilaksanakan di 
rumah produksi. Pada pelatihan ini mula-mula peserta diperkenalkan dengan buku jurnal dan buku besar keuangan. Selanjutnya peserta dilatih untuk mencatat semua pengeluaran dan pemasukan pada buku jurnal dan buku besar (Gambar 4). Hasil dari kegiatan pelatihan ini adalah anggota PKK sudah mengenal istilah buku jurnal dan buku besar keuangan, serta sudah memiliki kebiasaan untuk mencatat pemasukkan dan pengeluaran setiap kali produksi. Kendala yang dihadapi oleh peserta adalah peserta masih kesulitan dalam membedakan akun yang didebit dan akun yang dikredit saat pencatatan di buku besar, sehingga kedepannya anggota PKK perlu diberi pelatihan kembali dan dievaluasi secara berkala.

\section{Pelatihan Pemasaran}

Pada kegiatan ini, anggota kelompok PKK diberikan pelatihan strategi pemasaran offline dan online. Pelatihan pemasaran (offline) bertujuan untuk melatih anggota PKK mempromosikan produk keripik pisangnya melalui: 1) Orang terdekat dengan cara membagikan informasi produk ke semua nomor telfon yang

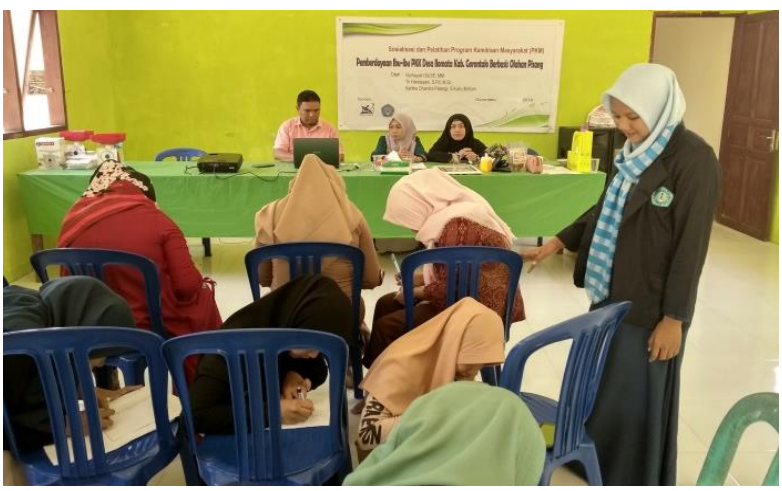

a

dimiliki peserta; 2) Menitipkan produk keripik pisang di kios-kios dan rumah makan yang ada di Desa Ilomata dan sekitarnya; 3) Memanfaatkan jejaring PKK untuk mempromosikan maupun menjual produk keripik dengan cara mengikutkan produk pada kegiatan-kegiatan yang diadakan oleh kelompok PKK baik di tingkat kecamatan maupun di kabupaten. Hal ini dikarenakan jejaring organisasi PKK pada umumnya terorganisir secara baik dan kegiatannya juga sudah melembaga dan menjadi bagian dari kehidupan masyarakat (Hamid et al. 2018).

Sementara itu, pelatihan pemasaran online diberikan kepada anggota kelompok PKK dengan tujuan agar anggota PKK dapat memanfaatkan media internet sebagai sarana pemasaran produk untuk memperoleh pangsa pasar yang lebih luas. Bentuk pelatihan yang dilakukan adalah 1) Memperkenalkan kepada anggota PKK terkait media-media online yang memungkinkan untuk memasarkan produk; 2) Melatih anggota PKK membuat halaman facebook (fb); dan 3) Melatih anggota PKK untuk memasarkan produk di market place $\mathrm{fb}$ yang dimiliki peserta (Gambar 5).

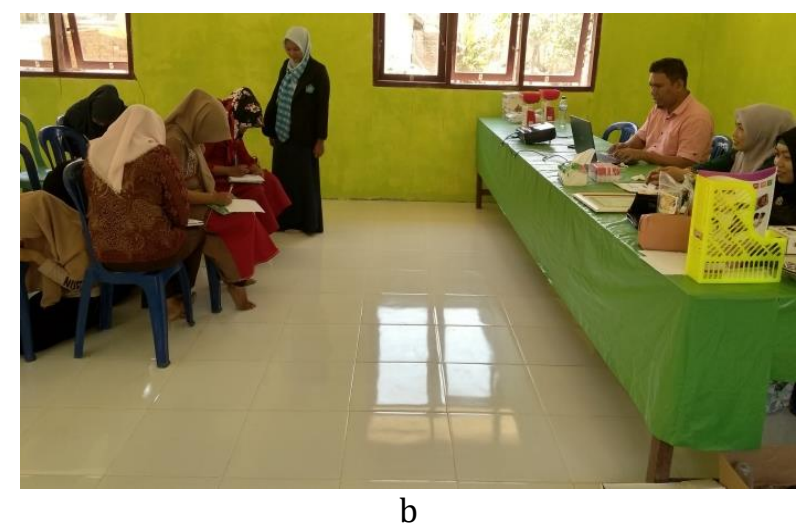

Gambar 4 Pelatihan pembukuan sederhana dan pemasaran.

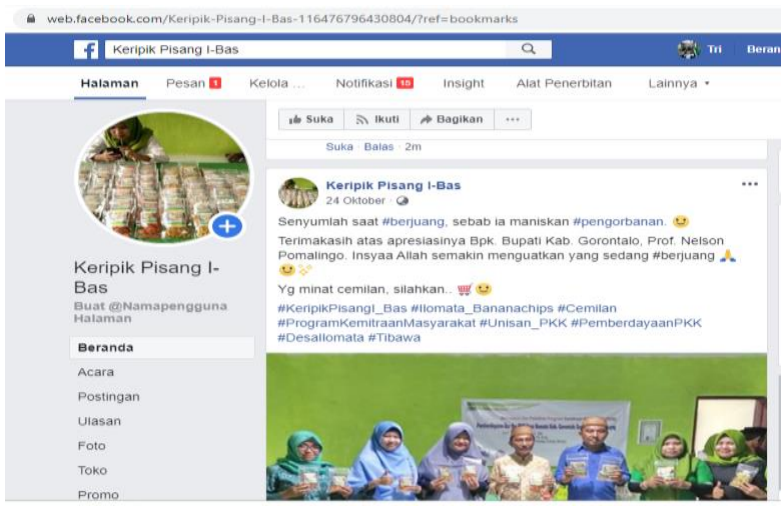

a

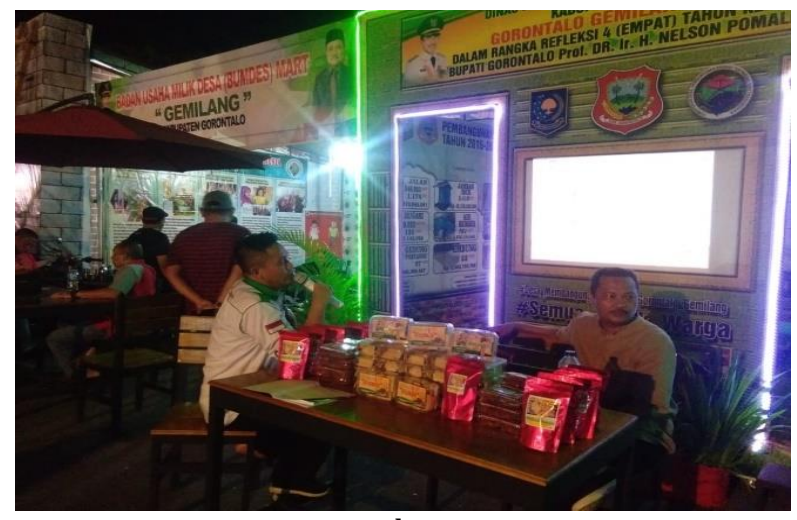

b

Gambar 5 a) Pemasaran produk keripik pisang melalui halaman faceebook dan b) Pemasaran produk melalui kegiatan-kegiatan yang diselenggarakan oleh PKK/Pemda. 
Hasil dari pelatihan ini adalah 1) Anggota PKK telah memahami dan memiliki keterampilan terkait pemasaran produk baik secara offline maupun online; 2) Tersedianya produk keripik pisang Kelompok PKK Desa Ilomata di kios-kios dan rumah makan di sekitar Desa Ilomata; 3) Produk keripik mulai diikutkan pada kegiatankegiatan yang dilaksanakan oleh kelompok PKK maupun pemda; dan 3) Tersedianya halaman fb untuk pemasaran produk keripik pisang. Hasil dari pelatihan ini juga menyebabkan semakin dikenalnya produk keripik pisang dari Desa Ilomata, sehingga meningkatkan jumlah produksi keripik dalam setiap kali produksinya, yaitu dari 50 pcs menjadi $100-150$ pcs. Menurut Wandanaya (2012) program pemasaran online berpengaruh pada keputusan pembelian dengan memerhatikan manfaat yang diperoleh oleh pelanggan di antaranya nyaman, akses, dan pilihan produk yang lebih besar, interaktif, dan segera, dan memberikan akses kebanyak informasi.

Adapun kendala yang dihadapi, yaitu jaringan internet yang kadang kurang bagus sehingga memengaruhi kecepatan respons penjual dalam menjawab maupun menindaklanjuti pemesanan. Sehingga kedepannya perlu kerja sama dengan pemerintah desa melalui anggaran dana desa untuk meningkatkan layanan internet yang ada di Desa.

\section{Kegiatan Pendampingan}

Pada tahapan ini, kegiatan pendampingan yang dilakukan meliputi penentuan nama produk keripik pisang sebagai identitas produk, pembuatan label kemasan dan pengurusan izin edar PIRT. Dari hasil diskusi bersama seluruh anggota PKK diputuskan nama produk keripik pisang yang dirintis oleh kelompok PKK Desa Ilomata yaitu Keripik Pisang I-Bas (Ilomata-Banana chips).

Pendampingan dalam pengurusan izin edar PIRT bertujuan agar produk keripik pisang yang dihasilkan dapat terjamin keamanannya serta dapat dipasarkan di pangsa pasar yang lebih luas. Izin edar PIRT merupakan jaminan resmi dari pemerintah agar produk dapat beredar dan aman dikonsumsi bagi seluruh konsumen. PIRT dikeluarkan melalui badan pengawas yaitu Dinas Kesehatan yang terdapat di suatu Kabupaten (BPOM 2012). Kegiatan pendampingan ini berupa pendampingan dalam menyiapkan dokumen persyaratan, melakukan pendaftaran, pendampingan dalam mengikuti sosialisasi keamanan pangan yang diselenggarakan oleh Dinas Kesehatan Kab. Gorontalo, serta pendampingan dalam menyiapkan sarana produksi saat dilakukan pemeriksaan oleh petugas dari Dinas Kesehatan. Hasil dari pendampingan ini berupa sertifikat PIRT dengan No. 214750201001324 (Gambar 6).

\section{SIMPULAN}

Kegiatan pengabdian masyarakat dalam bentuk pemberdayaan kelompok PKK Desa Ilomata, Kecamatan Tibawa, Kabupaten Gorontalo melalui wirausaha keripik pisang aneka rasa difokuskan pada kegiatan pelatihan pembuatan keripik pisang aneka rasa, pelatihan pembukuan sederhana, dan pelatihan pemasaran produk. Produk keripik pisang yang dihasilkan diberi nama keripik pisang I-Bas (Ilomata-Banana chips) dengan nomor izin edar PIRT 214750201001324 dan telah dipasarkan baik secara offline maupun online. Untuk keberlanjutan program ini disarankan kepada anggota kelompok PKK agar senantiasa berlatih secara mandiri terkait keterampilan-keterampilan yang telah diajarkan serta diperlukan pula kerja sama dengan pemerintah desa agar dapat memberikan motivasi dan pendampingan kepada anggota kelompok PKK secara kontinu.

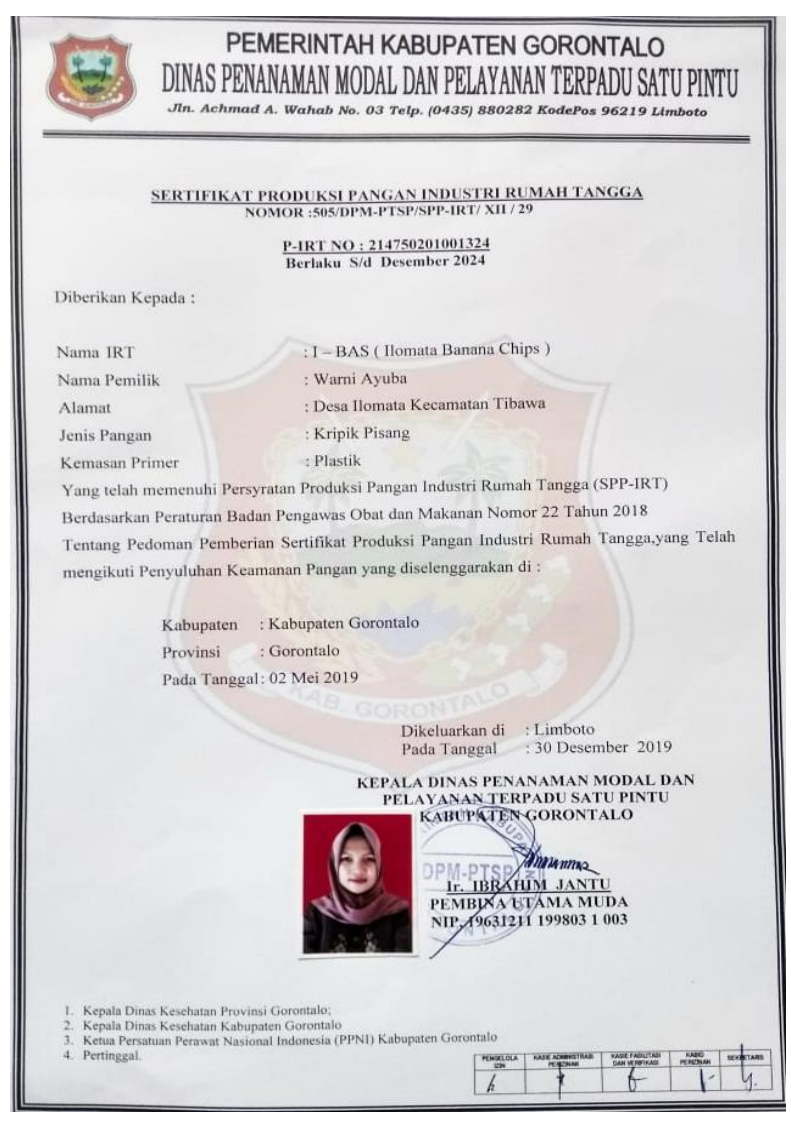

Gambar 6 Sertifikat PIRT kelompok I-Bas. 


\section{UCAPAN TERIMA KASIH}

Terima kasih penulis ucapkan kepada Kementerian Riset, Teknologi dan Peguruan Tinggi atas Dana Hibah Program Kemitraan Masyarakat (PKM) dan seluruh pihak yang telah membantu.

\section{DAFTAR PUSTAKA}

Anggoro K. 2016. Aklimasi Pisang (Musa paradisiaca L.) Pada Variasi Varietas dan Dosis Fungi Mikoriza Arbuskula. [Skripsi]. Purwokerto (ID): Universitas Muhammadiyah Purwokerto.

[BPOM] Badan Pengawas Obat dan Makanan. 2012. Pedoman Pemberian Sertifikat Produksi Pangan Industri Rumah Tangga. [Internet]. [diakses Maret 2020]. Tersedia pada http://standarpangan.pom.go.id.

[BPP] Balai Penyuluhan Pertanian Kecamatan Tibawa. 2017. Komoditas Pertanian Desa Ilomata. Kantor Desa Ilomata Kecamatan Tibawa Kabupaten Gorontalo.

[BSN] Badan Standar Nasional. 1996. SNI 014315-1996 tentang keripik pisang. [Internet]. [diakses Februari 2021] Tersedia pada: https://dokumen.tips/documents/sni-014315-1996-keripik-pisang.html

Ekaputri S. 2013. Perbandingan Keragaman Morfologi Pisang Kepok Unti Sayang (Musa balbisiana) Hasil Subkultul 1 sampai 6. [Skripsi]. Bogor (ID): Institut Pertanian Bogor.

Hamid RS, Anwar SM, Rahmatia, Ikbal M. 2018. Pemberdayaan Ibu-Ibu Pkk Melalui Social Preneur Sebagai Upaya Dalam Meningkatkan Kesejahteraan Masyarakat Di Desa Pettalandung. Jurnal Dedikasi Masyarakat.
2(1): 23-29. https://doi.org/10.31850/ jdm.v2i1.362

Hartoyo, Koswara, S, Sulassih, Megawati LR. 2019. Peningkatan Nilai Tambah Usaha Olahan Keripik Pisang di Desa Tenajar, Kabupaten Indramayu, Jawa Barat. Agrokreatif Jurnal Ilmiah Pengabdian kepada Masyarakat. 5(3): 251-257. https://doi.org/ 10.29244/agrokreatif.5.3.251-257

Mudjajanto E, Kustiyah L. 2006. Membuat Aneka Olahan Pisang (Peluang bisnis yang menjanjikan). Tangerang (ID): PT. Agromedia Pustaka.

Nugraheni M. 2018. Pengolahan pisang dan singkong. Disampaikan pada: Pelatihan Pengolahan singkong dan pisang di KWT Gotong Royong, Pringombo B, Rongkop Gunung Kidul. Yogyakarta (ID): Minggu, 27 Mei 2018.

Puspita CR. 2016. Pendugaan Umur Simpan Keripik Pisang Kepok (Musa acuminate sp.) Dalam Berbagai Jenis Kemasan dengan Model Pendekatan Arrhenius. [Skripsi]. Lampung (ID): Universitas Lampung.

Rinaldo E, Marpaung CM, Hogantara A. 2018. Peta Jalan UKM 4.0 (Profesional, Produktif, Kratif, dan Entrepreneurial). Jakarta (ID): PT Gramedia Pustaka Utama.

Santoso B. 2010. Skema dan Mekanisme Pelatihan. Jakarta (ID): Penerbit Terangi.

Suhartono A. 2011. Studi Pembuatan Roti dengan Substitusi Tepung Pisang Kepok (Musa paradisiaca L.). [Skripsi]. Makassar (ID): Universitas Hasanuddin.

Wandanaya AB. 2012. Pengaruh Pemasaran Online Terhadap Keputusan Pembelian Produk. Creative Communication and Innovative Technology Journal. 5(2): 174-185. https://doi.org/10.33050/ccit.v5i2.149 